\title{
EFFECTS OF BACTERIAL VAGINOSIS ON PERINATAL OUTCOME
}

\author{
Rajshree Seth¹, Manju Maheshwari², Leena Saini' ${ }^{3}$, Vikrant Sharma ${ }^{4}$
}

\section{HOW TO CITE THIS ARTICLE:}

Rajshree Seth, Manju Maheshwari, Leena Saini, Vikrant Sharma. "Effects of Bacterial Vaginosis on Perinatal Outcome". Journal of Evolution of Medical and Dental Sciences 2014; Vol. 3, Issue 08, February 24;

Page: 2040-2046, DOI: $10.14260 /$ jemds/2014/2100

ABSTRACT: INTRODUCTION: Bacterial vaginosis is a condition in which the normal lactobacillus (predominant vaginal flora) is replaced with anaerobic bacteria, gardnerella vaginalis and mycoplasma hominis. Our study was designed to find out the effects of bacterial vaginosis on fetomaternal outcome in pregnant women. MATERIAL \& METHODS: A prospective study was conducted in MGMCH, Jaipur from September'12 to February '13. 100 women attending the antenatal clinic were recruited during their antenatal visit after 20 weeks of gestation and observed for presence of bacterial vaginosis and followed till pregnancy outcome. Prevalence of bacterial vaginosis was determined by Nugent and Amsel criteria. Maternal and neonatal morbidity were studied accordingly. RESULT: Prevalence of bacterial vaginosis by Nugent criteria was $19 \%$. There was a significant association between the period of gestation at which the patient delivers and Nugent scoring of her gram stain picture $(\mathrm{p}=0.01)$. Relationship between nursery admissions of baby and bacterial vaginosis was found to be highly significant ( $\mathrm{p}=0.01)$. Out of the 100 babies delivered, $20 \%$ had low birth weight, $2 \%$ had birth asphyxia \& Apgar score $<5,7 \%$ delivered prematurely \& $14 \%$ babies had to be transferred to neonatal care units for various causes. CONCLUSION: Bacterial vaginosis was found to be significantly associated with adverse pregnancy outcome in the form of increased risk of preterm delivery, low birth weight, birth asphyxia in neonate. It was also concluded that there was a definite role of treatment because it can prevent a considerable number of preterm deliveries.

KEYWORDS: Bacterial vaginosis, Preterm birth, Antibiotics, Low birth weight, Pregnancy outcome

BACKGROUND: Bacterial vaginosis is a condition in which the normal lactobacillus (predominant vaginal flora) is replaced with anaerobic bacteria, gardnerella vaginalis and mycoplasma hominis. ${ }^{1}$ Current studies have found the prevalence of bacterial vaginosis among non-pregnant women to range from 15 percent to 30 percent; upto 50 percent of pregnant women have been found to have bacterial vaginosis. ${ }^{2,3}$

Previously considered a benign condition, bacterial vaginosis has been related to many complications of pregnancy including chorioamnionitis, preterm delivery, preterm labor, premature rupture of membranes and possibly spontaneous abortion and many gynecological conditions including pelvic inflammatory disease, post hysterectomy vaginal cuff cellulitis and endometritis.

Among the complications of bacterial vaginosis, the most significant and well documented association is that between bacterial colonization of vagina and preterm labor. The present study aims at determining the correlation between vaginal $\mathrm{pH}$ alteration, vaginal infections and likelihood of preterm labor and whether treatment causes a significant alteration in the pregnancy outcome in women with a documented high vaginal $\mathrm{pH}$ and vaginal infection. 
AIMS:

1. To estimate the prevalence of bacterial vaginosis during pregnancy.

2. To study the fetal outcome in pregnancy with vaginal infection.

SETTINGS \& DESIGN: This study was conducted in the department of Obstetrics \& Gynecology and department of Microbiology, Mahatma Gandhi Hospital, Sitapura, Jaipur. Study design -Prospective study.

MATERIAL \& METHODS: 200 subjects were selected from the patients attending antenatal clinic from April 2012 - April 2013 with gestational age more than 20 weeks of pregnancy.

\section{Inclusion criteria:}

1. A singleton pregnancy.

2. Period of gestation $20 \mathrm{wk}$. onwards as calculated by last menstrual period or first obstetrical ultrasonography if the woman was not sure of her dates

\section{Exclusion criteria:}

1. Women with a history of previous preterm labor, threatened or established preterm labor.

2. The women with a known obstetrical complication such as antepartum hemorrhage, multiple gestation, chronic documented urinary tract infection, structural and functional anomalies of uterus.

3. Cases where preterm labor was induced for any medical or obstetrical indication.

A thorough general physical and obstetric examination was performed and all routine investigations sent. An obstetrical USG with information regarding gestational age, placental localization, any gross congenital malformation and general fetal well-being was carried out.

Examination of pH: An unlubricated sterile Sim's speculum is introduced and posterior vaginal fornix is exposed. The vaginal secretions are collected on Sim's speculum. A pH indicator strip is dipped in vaginal secretions and color is matched to the color interpretation chart.

\section{Collection of specimen for bacteriological examination:}

Two cotton tipped swabs are to be used to take specimen from posterior vaginal fornix. Simultaneously, character of vaginal discharge is to be noted:

One of the cotton tipped swab is to be rolled onto a glass slide and the smear is air dried. This is used for gram staining.

The other swab is placed into a sterile vial containing small amount of saline and a suspension of vaginal bacteria and cells made.

A drop of this solution is put on a glass slide and one drop of $10 \% \mathrm{KOH}$ is added to it and then sniffed for characteristic fishy odor (whiff test).

\section{Reading and interpretation of results:}

Is done according to the following two criteria: 
A. AMSEL ET AL (1983)

- The diagnosis of bacterial vaginosis is made if three of the following four signs are present.

1. Characteristic homogenous white, adherent discharge.

2. Vaginal $\mathrm{pH}>4.5$.

3. Release of fishy amine odor from vaginal fluid when mixed with $10 \% \mathrm{KOH}$.

4. Presence of clue cells (usually representing at least $20 \%$ of vaginal epithelial cells).

B. NUGENT ET AL (1990)

- Each gram stained smear is evaluated for the following morphotypes under oil immersion lens.

1. Large gram positive rods - lactobacillus morphotype.

2. Small gram negative rods - gardnerella morphotype.

3. Small gram variable rods - bacteroids morphotype.

4. Curved gram variable rods - mobilincus morphotype.

Each morphotype is quantitated from $0+$ to $4+$ with regard to the number of morphotypes per oil immersion field.

\begin{tabular}{|l|c|c|c|c|c|}
\hline Morphotype & \multicolumn{5}{|c|}{ Points assigned } \\
\hline & 0 & 1 & 2 & 3 & 4 \\
\hline Lactobacillus & $4+$ & $3+$ & $2+$ & $1+$ & 0 \\
\hline Anaerobic rods & 0 & $1+$ & $2+$ & $3+$ & $4+$ \\
\hline & 0 & $1-2+$ & $3-4+$ & - & - \\
\hline
\end{tabular}

$$
\begin{aligned}
& 4+=>30 \text { morphotypes } / 1000 * \text { field } \\
& 3+=6-30 \text { morphotypes } / 1000 * \text { field } \\
& 2+=1-5 \text { morphotypes } / 1000 * \text { field } \\
& 1+=<1 \text { morphotypes } / 1000 * \text { field }
\end{aligned}
$$

\section{Score:}

$$
\begin{aligned}
& 0-3 \text { - normal } \\
& 4-6 \text { - intermediate } \\
& 7 \text { - } 10 \text { - bacterial vaginosis }
\end{aligned}
$$

All women with $\mathrm{pH}>4.5$ and a documented infection on high vaginal swab received appropriate antibiotics. A repeat vaginal $\mathrm{pH}$ and high vaginal swab were taken after completion of antibiotic treatment.

The feto-maternal outcome was studied in terms of:

- Period of gestation at which the patient delivered.

- Birth weight and APGAR scores of the baby and admission to neonatal care units. 


\section{RESULTS:}

\begin{tabular}{|l|c|c|c|c|}
\hline Character of discharge & $\begin{array}{c}\text { Non-bacterial } \\
\text { vaginosis }\end{array}$ & Intermediate & $\begin{array}{c}\text { Bacterial } \\
\text { vaginosis }\end{array}$ & Total \\
\hline $\begin{array}{l}\text { a) Small amount of white } \\
\text { discharge or mucoid (Normal) }\end{array}$ & 54 & 12 & 8 & 74 \\
\hline $\begin{array}{l}\text { b) Moderate amount } \\
\text { white discharge }\end{array}$ & 84 & 8 & 16 & 108 \\
\hline $\begin{array}{l}\text { c) Large copious thin } \\
\text { grey adherent discharge }\end{array}$ & 4 & 0 & 14 & 18 \\
\hline \multicolumn{1}{|r|}{ Total } & 142 & 20 & 38 & 200 \\
\hline \multicolumn{2}{r}{ Table 1: Character of Vaginal Discharge } \\
\end{tabular}

The above table depicts the character of vaginal discharge. Out of the $18 / 200$ patients having large copious thin grey adherent discharge, 14 were having Bacterial vaginosis whereas, in 108/200 patients having moderate amount of white discharge, only 16 had Bacterial vaginosis. Large copious thin grey adherent discharge was characteristic of Bacterial vaginosis. $\mathrm{P}=0.0001$ (very highly significant).

\begin{tabular}{|c|c|c|}
\hline $\begin{array}{c}\text { pH of vaginal } \\
\text { discharge }\end{array}$ & $\begin{array}{c}\text { Frequency } \\
\mathbf{n = 2 0 0}\end{array}$ & Percentage \\
\hline$\leq 4$ & 160 & $80 \%$ \\
\hline 5 & 6 & $3 \%$ \\
\hline$\geq 6$ & 34 & $17 \%$ \\
\hline \multicolumn{2}{|c|}{ Table 2: pH of vaginal Discharge } \\
\hline
\end{tabular}

Above table depicts the $\mathrm{pH}$ of vaginal discharge. The $\mathrm{pH}$ value suggestive of bacterial vaginosis ( $>4.5$ ) was found in 40 out of 200 patients studied.

\begin{tabular}{|c|c|c|}
\hline $\begin{array}{c}\text { Amine odor test } \\
\text { of vaginal discharge }\end{array}$ & Frequency & Percentage \\
\hline Negative & 166 & $83 \%$ \\
\hline Positive & 34 & $17 \%$ \\
\hline
\end{tabular}

\section{Table 3: Amine odor Test of Vaginal Discharge}

Out of $34 / 200$ patients i. e $17 \%$ of the patients, had positive whiff test consistent with diagnosis of bacterial vaginosis.

\begin{tabular}{|c|c|c|}
\hline $\begin{array}{c}\text { Clue cells in } \\
\text { wet mount }\end{array}$ & Frequency & Percentage \\
\hline Present & 166 & $83 \%$ \\
\hline Absent & 34 & $17 \%$ \\
\hline
\end{tabular}

Table 4: Clue Cells in Wet Mount Preparation

Out of $34 / 200$ patients i. e $17 \%$ of the patients, had clue cells in wet mount preparation consistent with diagnosis of bacterial vaginosis. 


\begin{tabular}{|l|c|c|}
\hline $\begin{array}{c}\text { Vaginal microflora } \\
\text { (NUGENT SCORING) }\end{array}$ & $\begin{array}{c}\text { Frequency } \\
\mathbf{n = 2 0 0}\end{array}$ & Percentage \\
\hline Not bacterial vaginosis & 142 & $71 \%$ \\
\hline Intermediate & 20 & $10 \%$ \\
\hline Bacterial Vaginosis & 38 & $19 \%$ \\
\hline \multicolumn{3}{|c|}{ Table 5: Vaginal Microflora as evaluated by } \\
\multicolumn{2}{|c|}{ vaginal Gram Stain Smear (Nugents Scoring) } \\
\hline
\end{tabular}

According to interpretation of vaginal gram stain by Nugent's criteria, 19\% of the pregnant women were diagnosed as Bacterial vaginosis, $10 \%$ of women were diagnosed as having intermediate flora and $71 \%$ of women had picture consistent with Non bacterial vaginosis.

\begin{tabular}{|c|l|c|c|}
\hline 1 & \multicolumn{1}{|c|}{$\begin{array}{c}\text { Repeat } \\
\text { after diagnosis }\end{array}$} & $\begin{array}{c}\text { No. of patients } \\
\text { N=38 }\end{array}$ & Percentage \\
\hline Bacterial vaginosis & Non bacterial vaginosis & 24 & $63.15 \%$ \\
\hline Bacterial vaginosis & Intermediate & 8 & $21.05 \%$ \\
\hline Bacterial vaginosis & Bacterial vaginosis & 2 & $5.26 \%$ \\
\hline Bacterial vaginosis & Could not be followed & 4 & $10.52 \%$ \\
\hline \multicolumn{2}{|r|}{ Table 6: Repeat swabs of patients after antibiotic } \\
treatment with Bacterial vaginosis in 1 1st screening
\end{tabular}

Out of the 38/200 patients diagnosed as bacterial vaginosis, 4 patients could not be followed $(10.52 \%)$. Of the 34 patients who were given antibiotic treatment and were followed by a repeat HVS, 32 (84. 1\%)patients had some kind of improvement in the Gram stain picture (either changing to normal or to intermediate form)whereas 2 patients continued to show Bacterial vaginosis, i. e 5. $26 \%$.

\begin{tabular}{|l|c|c|}
\hline \multicolumn{1}{|c|}{ Outcome } & Number & Percentage \\
\hline 1. Low birth weight <2500g & 40 & $20 \%$ \\
\hline 2. Birth Asphyxia Apgar $\leq 5$ & 2 & $1 \%$ \\
\hline 3. Prematurity $\leq 37$ weeks & 14 & $7 \%$ \\
\hline 4. Gross Congenital Anomaly & 0 & $0 \%$ \\
\hline $\begin{array}{l}\text { 5. Admission to Nursery or } \\
\text { Neonatal care unit }\end{array}$ & 28 & $14 \%$ \\
\hline 6. Normal Table 7: Fetal Outcome \\
\hline \multicolumn{2}{|r|}{} \\
\hline
\end{tabular}

Out of the 200 babies delivered, 40 had low birth weight, 2 had birth asphyxia and Apgar scores $\leq 5,14$ delivered prematurely and 28 babies had to be transferred to neonatal care units for various causes. Rest 116 babies were delivered healthy.

DISCUSSION: Infection as a possible cause of preterm labor has caused much interest recently (Minkoff et al) ${ }^{4}$ and most of the evidence relating to preterm labor is based on two observations. First, all types of infections relating to ascending bacterial invasions including chorioamnionitis, 
neonatal sepsis and maternal endometritis are more commonly found in preterm births. Second, certain organisms in the vaginal flora are more often found in women with preterm labor or premature rupture of membranes. Govender et at $(1996)^{5}$ showed that $46 \%$ of the women studied had poor pregnancy outcome as measured by obstetrical complication, pregnancy loss and/or neonatal morbidity.

There was a significant difference in the outcome in women with bacterial vaginosis (55of 88) compared to those infections other than bacterial vaginosis (13 of 31) or no infection (5of 9). This difference was for obstetrical complications of preterm delivery, PROM and intrauterine infection but not for pregnancy losses and neonatal morbidity. Neonatal infections occur more often in prematures (Daikoku et al, 1981) ${ }^{6}$. The bacteria causing neonatal infections are generally the same as those causing amnionitis and are frequent isolates of the vagina (Naeye et al, 1971) 7 .

In our study: 200 women attending the antenatal clinic of Mahatma Gandhi Hospital were recruited during their antenatal visit at 20 weeks onwards and observed for presence of vaginal infections including bacterial vaginosis (particularly associated with preterm labor)and were followed till their pregnancy outcome. Those women, in which documented vaginal infection was present, were given antibiotics (metronidazole 400mg BDx7 days). A repeat high vaginal swab was taken after completion of antibiotic treatment to see the response to treatment. The diagnosis of bacterial vaginosis was made by three different criteria that is the clinical criteria by Amsel (1983)8 and gram stain scoring system by Nugent (1991) ${ }^{9}$. By using Amsel's criteria, 17\% of the patients were diagnosed as bacterial vaginosis. By using Nugent's criteria, 142 out of 200 patients $(71 \%)$ had Gram stain picture consistent with non-bacterial vaginosis i. e. Nugent's score $0-3,10 \%$ patients had Nugent's scores consistent with intermediate and 19\% patients were diagnosed as bacterial vaginosis (Nug. Scores 7-10). There was improvement in the gram stain picture of patients initially diagnosed as bacterial vaginosis in $84.21 \%$ [i. e. 32 out of 38] patients after treatment with oral metronidazole. Preterm delivery occurred in 14 out of 200 women studied. The rest $93 \%$ delivered at term. Out of the 14 patients delivered preterm, 8 had bacterial vaginosis. At the same time, out of the total 38 patients which had bacterial vaginosis by Nugents criteria, 30 patients delivered after 37 weeks. All the patients who had bacterial vaginosis had received oral metronidazole treatment. So it was concluded that though treatment of bacterial vaginosis in pregnancy cannot assure the patient going into preterm labor, it has been shown that there is definite role of treatment because it can prevent a considerable number of preterm deliveries. There has been a significant association between the POG at which the patient delivers and Nugent scoring of her gram stain picture $(\mathrm{P}=0.015)$. Two babies had poor Apgar score $(\leq 5)$ out of which, one belonged to bacterial vaginosis group \& the other one belonged to nonbacterial vaginosis group. Total 28 babies had to be transferred to nursery out of which 8 babies were from non-bacterial vaginosis group, 18 were from bacterial vaginosis group \& 2 were from intermediate group. The relationship between nursery admission of baby and bacterial vaginosis was found to be very highly significant $(\mathrm{p}=0.001)$. Also a very highly significant correlation was found between baby weight and gram stain picture of the women ( $\mathrm{P}=0.0007) .20$ out of 38 patients (52.5\%) having bacterial vaginosis had birth weight of babies $<2.5 \mathrm{~kg}$ whereas only 20 out of 142 patients of nonbacterial vaginosis group had birth weight of $<2.5 \mathrm{~kg}$ showing the effect of bacterial vaginosis on low birth weight of babies. 
CONCLUSION: Bacterial Vaginosis was found to be significantly associated with adverse pregnancy outcome in the form of Increased risk of preterm delivery, Low birth weight, Birth asphyxia in neonate of bacterial vaginosis cases. It was also concluded that there was a definite role of treatment because it can prevent a considerable number of preterm deliveries.

\section{REFERENCES:}

1. Hillier SL, Krohn MA, Rabe LK, Klebanoff SJ, Eschenbach DA. The normal vaginal flora, $\mathrm{H}_{2} \mathrm{O}_{2^{-}}$ producing lactobacilli, and bacterial vaginosis in pregnant women. Clin Infect Dis. 1993 Jun;16 Suppl 4:S273-81.

2. Holzman C, Leventhal JM, Qiu H, Jones NM, Wang J. BV Study Group. Factors linked to bacterial vaginosis in nonpregnant women. Am J Public Health. 2001 Oct;91 (10) :1664-70.

3. McGregor JA, French JI. Bacterial vaginosis in pregnancy. Obstet Gynecol Surv. 2000 May;55 (5 Suppl 1) :S1-19.

4. Minkoff H, Grunebaum A. N, Schwarz R. H Feldman J, Cummings M, Crombleholme W, Clark l, Pringle G, Mc Cormack W. M. Risk factors for prematurity and PROM a prospective study of vaginal flora in pregnancy. American J Obstet Gynecol 1984; 150: 965-972.

5. Govender L, Hoosen AA, Moodley J, Moodley P, Sturm AW. Bacterial vaginosis and associated infections in pregnancy. Int J Gynaecol Obstet. 1966 Oct;55 (1) : 23-28.

6. Daikoku NH, Kalteider DF, Johnson TRB Jr et al. Premature rupture of the membranes and preterm labor: neonatal infection and perinatal mortality risks. Obstet Gynecol 1981;58;417.

7. Naeye RL-Dellinger WS, Bllanc WA. Fetal and maternal features of antenatal bacterial infection. J Pediatr. 1971;79;733.

8. Amsel R, Totten P, Spiegel CA, Chen KCS, Eschenbach DA, Holmes KK. Nonspecific vaginitis: diagnostic criteria and microbial and epidemiological associations. Am J Med. 1983;74:1422.

9. Nugent RP, Krohn MA. Hillier SL. Reliability of diagnosing bacterial vaginosis is improved by a standardized method of Gram stain interpretation J Clin Microbiol, Feb; 29; 297-301.

\section{AUTHORS:}

1. Rajshree Seth

2. Manju Maheswari

3. Leena Saini

4. Vikrant Sharma

\section{PARTICULARS OF CONTRIBUTORS:}

1. Post Graduate, Department of Obstetrics and Gynaecology, Mahatma Gandhi Medical College and Hospital, Jaipur.

2. Professor, Department of Obstetrics and Gynaecology, Mahatma Gandhi Medical College and Hospital, Jaipur.

3. Senior Resident, Department of Obstetrics and Gynaecology, Metro Mas Hospital, Jaipur
4. Senior Resident, Department of General Surgery, S. M. S Hospital, Jaipur.

\section{NAME ADDRESS EMAIL ID OF THE CORRESPONDING AUTHOR:}

Dr. Rajshree Seth, C-96, Kirti Nagar, New Delhi - 110015

E-mail: rajshree_15@yahoo.com

Date of Submission: 23/01/2014. Date of Peer Review: 24/01/2014. Date of Acceptance: 08/02/2014. Date of Publishing: 22/02/2014. 